\title{
Study on the Application of Rapid Excavation Technology in Rock
}

\section{Tunneling}

\author{
Jingfeng $\mathrm{Hou}^{1,2, \mathrm{a}}$, Zhong $\mathrm{Xu}^{2, \mathrm{~b}}$ and Dongming Guo ${ }^{1,3, \mathrm{c}}$ \\ ${ }^{1}$ State Key Laboratory for GeoMechanics \& Deep Underground Engineering, Beijing, 100083, \\ China \\ ${ }^{2}$ School of Civil and Transportation Engineering, Beijing University of Civil Engineering \& \\ Architecture, Beijing, 100044, China \\ ${ }^{3}$ School of Mechanics \& Civil Engineering, China University of Mining and Technology (Beijing), \\ Beijing, 100083, China \\ ahoujingfeng@bucea.edu.cn, b1013569557@qq.com, cdmguo@cumtb.edu.cn
}

Keywords: Rapid Excavation Technology, Rock Tunneling, Blasting parameters design.

Abstract. Based on the situation of low level on coal mine excavation in China, the paper discusses the main influence parameters in rock blasting design. And through a case study, the paper delivers a way to improve excavation velocity by optimizing blasting parameters and labor organization.

\section{Introduction}

Chinese coal industry have developed rapidly in recent years, however, Chinese coal mine excavation technology which is still in low level cannot catch up with the development of coal industry. According to the author's research, there are two methods to improve coal mine excavating velocity. One way is to improve mechanization level; the other way is to make full use of the technological potential of drill-blasting method, which is used widely in coal excavation.

Commonly in China, using integrated tunneling equipments means high cost, especially in rock tunnel. However, by optimizing blasting parameters and labor organization of traditional drill-blasting method, the excavating velocity can be more than $120 \mathrm{~m}$ per month; and even can reach $150 \mathrm{~m}$ per month. This can conform mechanization excavating velocity and at the same time with lower cost.

This paper studies traditional drill-blasting method by analyzing blasting parameters and labor organization of actual case to deliver a rapid excavation technology in coal rock tunneling.

\section{Blasting parameters design and analysis}

The rapid excavation blast parameters in rock tunneling are closely related with the unit explosive consumption, the circulation depth of boreholes and the number of boreholes. There are many researches on the calculation of these parameters, which provide references for optimal designing.

\section{Unit explosive consumption.}

Unit explosive consumption means the explosive consumption per stere original rock, which is commonly replaced as "q". It's a very important parameter, for it influences not only rock fragmentation, flying distance and muck-pile profile, but also boreholes efficiency, rock tunnel 
outline and surrounding rock stability etc. So it has significance in blasting parameters design of speedy drivage.

Unit explosive consumption depends on many factors, such as explosive properties, rock properties, tunnel cross section, charge diameter, borehole length and diameter etc. So it is difficult to be accurately calculated. In practice, $\mathrm{q}$ is calculated through empirical formula, and adjusted in operation.

Protodyakonov's empirical formula as (1)

$$
q=1.1 k_{o} \sqrt{f / s} \quad\left(\mathrm{~kg} / \mathrm{m}^{3}\right)
$$

Where: $q$ - unit explosive consumption, $\mathrm{kg} / \mathrm{m}^{3}$;

$k_{o}$ - blasting force correction coefficient, $k_{o}=525 / \mathrm{p}, \mathrm{p}$ - blasting force $(\mathrm{mL})$;

$f$ - Protodyakonov's coefficient;

$s$ - tunnel cross section area, $\mathrm{m}^{2}$.

\section{Another empirical formula as (2)}

$$
q=\left(\sqrt{\frac{f-4}{1.8}}+4.8 \times 10^{-0.15 s}\right) \text { ck } \phi e \quad\left(\mathrm{~kg} / \mathrm{m}^{3}\right)
$$

Where: q- unit explosive consumption, $\mathrm{kg} / \mathrm{m}^{3}$;

$f$ - Protodyakonov's coefficient;

$s$ - tunnel cross section area, $\mathrm{m}^{2}$;

$c$ - charge diameter correction coefficient;

$k$ - blasting force correction coefficient, $k=360 / \mathrm{p}, \mathrm{p}$ - blasting force $(\mathrm{mL})$;

$\phi$ - charge density correction coefficient, in common situation, $\phi=0.78 \sim 0.80$;

$e$ - borehole depth correction coefficient.

\section{Borehole depth}

Borehole depth is also a very important parameter in tunnel excavation, which influences not only each working procedure, completion time and driving speed, but also affects the blasting effect and material consumption. At the same time, borehole depth is an important factor to the circulation frequency. At present, there are two kinds of technology in China, one is shallow borehole with more circulation; and the other is deep borehole with less circulation. As to which way we should adopt depends on specific conditions. The best borehole depth is the depth with smallest labor or manhour and lowest cost drivage roadway per meter. Usually, the borehole depth is determined according to the mission requirements or circulation organization.

\section{The calculation of borehole length by monthly progress as formula (3)}

$$
l=\frac{L}{N n \eta \eta_{1}}
$$

Where: L-tunnel length of monthly scheme, m;

$N$ - days per month for tunneling work, $\mathrm{d}$;

$n$ - number of cycle completed every day;

$\eta$ - utilization rate of borehole, in common situation, $\eta=0.85 \sim 0.9$;

$\eta_{1}$ - Normal circulation rate, in common situation, $\eta_{1}=0.85 \sim 0.9$; 


\section{Borehole length determined by the tunneling cycle organization as formula (4)}

$$
l=\frac{T-t}{\Phi \frac{N}{m v}+\frac{S \eta K}{n P}}
$$

Where: $T$ - a circle time of tunneling, h;

$t$ - except drilling and mucking time, the sum of the other process unparallel operation time, in common situation, $\mathrm{t}=1.0 \sim 1.5 \mathrm{~h}$;

$N$ - the number of borehole on working plane, Unit ;

$m$ - the number of rock drilling machine working at the same time;

$v$ - the drilling speed of rock drilling machine, $\mathrm{m} /(\mathrm{h} * \mathrm{set})$;

$\Phi$ - coefficient of single row drilling work, in common situation, $\Phi=0.3 \sim 0.6$;

$S$ - drivage sectional area, $\mathrm{m}^{2}$;

$\eta$ - utilization rate of borehole;

$K$ - the hulking coefficient of the rock, in common situation, $K=1.5 \sim 2.0$;

$n$ - the number of rock loading machine working at the same time;

$P$ - real productivity of rock loader, $\mathrm{m}^{3} /\left(\mathrm{h}^{*} \mathrm{set}\right)$;

\section{Borehole quantity}

The number of borehole directly affects drilling workload and blasting effect. Too little hole number, more big stones, Tunnel contour line is not smooth, even under-excavation phenomenon would happen. On the contrary, the drilling workload is too big, influences the driving speed. The main determinants: section size, rock properties, performance and unit consumption of explosive, borehole depth, etc. The principle of borehole number determined is on the premise of guarantee the blasting effect, reducing hole number as much as possible. Usually following the formula (5):

$$
N=3.3 \sqrt[3]{f S^{2}}
$$

Where: $N$ - number of boreholes;

$f$ - Rock consistence coefficient;

$S$ - Rock drivage section;

Meanwhile, the borehole number can be determined according to the required quantity of explosive and each borehole charge to calculate as formula (6):

$N=q S \eta m / \alpha \rho$

Where: $N$ - number of boreholes;

$q$ - explodes consumption per unit, $\mathrm{Kg} / \mathrm{m} 3$;

$S$ - Sectional area of tunnel, m2;

$\eta$ - Utilization of boreholes;

$m$ - Length of cartridge;

$\alpha$ - The average loading coefficient of borehole, in common situation, for cuthole $\alpha=0.7 \mathrm{~kg} / \mathrm{m}$, for collapse hole $\alpha=0.45 \sim 0.6 \mathrm{~kg} / \mathrm{m}$, for periphery hole $\alpha=0.1 \sim 0.35 \mathrm{~kg} / \mathrm{m}$;

$\rho$ - The weight of each cartridge, $\mathrm{kg}$. 


\section{Construction scheme}

\section{Project profile}

In this paper, the testing site selection for Daizhuang coal mine 6300 transport track alley, the tunnel section $14.2 \mathrm{~m}^{2}$, which lithology is sandstone, Protodyakonov's coefficient of surrounding rock $f=8 \sim 12$.

\section{Equipment allocation}

Artificial drilling and mechanical installed for the working face. The main equipment used as shown in table 1.

Table 1 The main equipments

\begin{tabular}{|c|c|c|c|c|}
\hline No. & Euipments & Specifications & Number & Notes \\
\hline 1 & Pneumatic drill & Y2T 8 (or 7655) & 6 & One for Standby \\
\hline 2 & Drag line & ZYP-3000 & 1 & \\
\hline 3 & $\begin{array}{c}\text { Pulp shooting } \\
\text { machine }\end{array}$ & HPC-VB & 2 & One for Standby \\
\hline 4 & Auxiliary fan & 22Kw & 2 & \\
\hline 5 & Initiator & MFB-200 & 3 & \\
\hline
\end{tabular}

\section{Blasting parameters}

The blasting scheme, blasting $1.8 \mathrm{~m}$ deep borehole excavating tunnelling less than $1.70 \mathrm{~m}$ per cycle. Wedge cut is adopted for slotting. $20 \mathrm{~m}$ long and $\Phi=35$ diameter drill rod is used, the depth of borehole is $1.8 \mathrm{~m}$ and the depth of Cuthole $200 \mathrm{~mm}$ deeper than others. The borehole arrangement is shown in figure 1.0, the firing order and explosive payload as shown in table 2, expected blasting effect are shown in table 3. It should be noted that the actual blasting parameters should be adjusted according to the actual lithology for the best blasting effect and the goal.
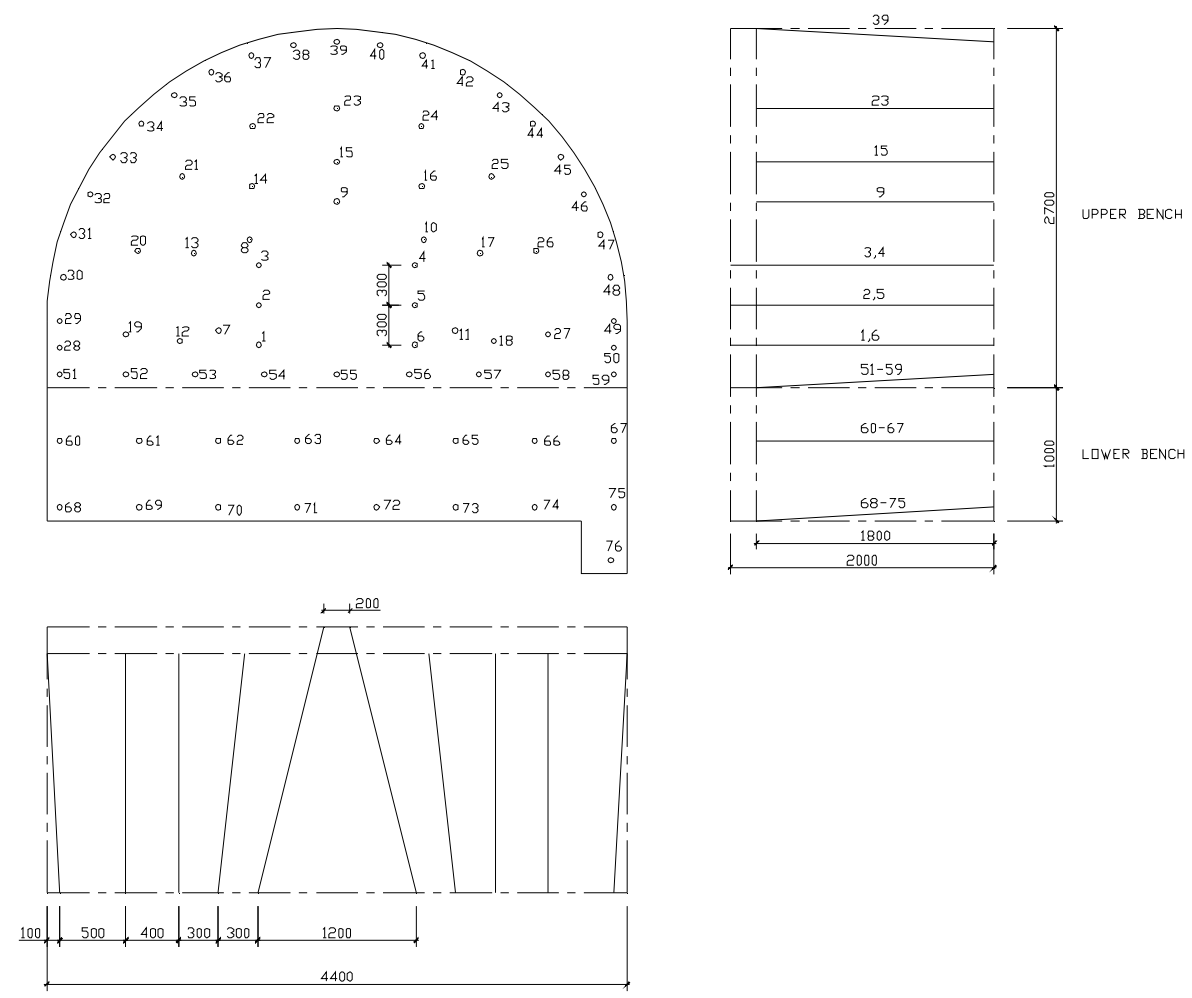

Fig. 1 The boreholes arrangement 
Table 2. Explosive charge weight

\begin{tabular}{|c|c|c|c|c|c|c|c|c|}
\hline & \multirow[b]{2}{*}{ No. } & \multirow{2}{*}{$\begin{array}{l}\text { Depth } \\
\quad( \\
\text { m) }\end{array}$} & \multirow{2}{*}{$\begin{array}{c}\text { Borehole } \\
\text { Spacing } \\
(\mathrm{mm})\end{array}$} & \multirow{2}{*}{$\begin{array}{l}\text { Resistance } \\
\text { Line(mm) }\end{array}$} & \multicolumn{3}{|c|}{ Explosive Charge (Kg) } & \multirow{2}{*}{$\begin{array}{l}\text { Blasting } \\
\text { Sequence }\end{array}$} \\
\hline & & & & & Number & $\begin{array}{c}\text { Charge per } \\
\text { Hole }\end{array}$ & Sum & \\
\hline Cutting Holes & $1-6$ & 2.0 & 300 & 1200 & 6 & 1.00 & 6.00 & 2 \\
\hline $\begin{array}{c}\text { Auxiliary } \\
\text { Holes }\end{array}$ & $7-11$ & 1.8 & 300 & 300 & 5 & 0.80 & 4.00 & 3 \\
\hline $\begin{array}{c}\text { Second Circle } \\
\text { Holes }\end{array}$ & $12-18$ & 1.8 & 600 & 400 & 7 & 0.80 & 5.60 & 3 \\
\hline $\begin{array}{c}\text { Third Circle } \\
\text { Holes } \\
\end{array}$ & $19-27$ & 1.8 & 600 & 400 & 9 & 0.80 & 7.20 & 3 \\
\hline $\begin{array}{c}\text { Periphery } \\
\text { Holes }\end{array}$ & $28-50$ & 1.8 & 300 & 500 & 23 & 0.40 & 9.20 & 4 \\
\hline Bottom Holes & $51-59$ & 1.8 & 500 & 500 & 9 & 0.80 & 7.20 & 5 \\
\hline \multirow{2}{*}{ Lower Bench } & $60-67$ & 1.8 & 600 & 400 & 8 & 0.80 & 6.40 & 2 \\
\hline & $68-75$ & 1.8 & 600 & 500 & 8 & 0.80 & 6.40 & \\
\hline Sum & & & & & 76 & & 52.00 & \\
\hline
\end{tabular}

Table 3.

Basting effect expected

\begin{tabular}{|c|c|c|c|c|c|}
\hline No. & Item & Result & No. & Item & Number \\
\hline 1 & Efficiency of borehole & $95 \%$ & 5 & $\begin{array}{c}\text { Circulating detonator } \\
\text { consumption }\end{array}$ & 75 \\
\hline 2 & Footage driving cycle & $1.70 \mathrm{~m}$ & 6 & $\begin{array}{c}\text { The unit consumption of } \\
\text { explosive }\end{array}$ & $\begin{array}{c}2.15 \\
\mathrm{Kg} / \mathrm{m}^{3}\end{array}$ \\
\hline 3 & Circulating solid rock volume & $\begin{array}{c}24.12 \\
\mathrm{~m}^{3}\end{array}$ & 7 & $\begin{array}{c}\text { The unit consumption of } \\
\text { detonator }\end{array}$ & $\begin{array}{c}3.10 \mathrm{per} \\
\mathrm{m}^{3}\end{array}$ \\
\hline 4 & $\begin{array}{c}\text { Circulating explosive } \\
\text { consumption }\end{array}$ & $52 \mathrm{Kg}$ & 8 & $\begin{array}{c}\text { Length of circulating } \\
\text { blasthole }\end{array}$ & $136.2 \mathrm{~m}$ \\
\hline
\end{tabular}

\section{Labor organization optimization}

According to Daizhuang coal mine field condition, equipment configuration and the status of the level of construction, the construction scheme adopts the "38" model to carry out, which is the two driving group to carry out every day, each group have two minor cycle; Meanwhile a guniting group is arranged to spray circularly every day.

\section{The application and benefit analysis.}

Based on the above theoretical analysis and experiment show that the rapid excavation scheme has better advantages. Before the test the circulating footage for one group is $1.6 \sim 1.8 \mathrm{~m}$, utilization of borehole is about $75 \%$, after the test the data is up to $3.4 \mathrm{~m}$ and $95 \%$, and the blasting effect is greatly increased. Obviously the new scientific labor organization form has obtained the good technical and economic effect and achieved safe, high-quality and high-efficiency footage above $140 \mathrm{~m}$ for three consecutive months for the Daizhuang coal mine 6300 orbital rock tunneling drivage. 


\section{Conclusion}

Rock tunneling drivage is a systematic engineering, and to achieve the goal of safe and efficient tunneling, the current situation is not very perfect in the case of mechanization. But the original drilling and blasting method for the optimization of blasting parameters, labor process improvement and the labor organization strengthened can also achieve increase in penetration effect. This topic through the above measures has the following conclusion:

(1) Drivage speed is generally more than $70 \%$ higher than the original, the speed of $140 \mathrm{~m}$ above monthly, above the same level, which assures the mine to keep high and stable yield in production.

(2) If the material consumption is greatly reduced, the tunneling is expected to save 200 yuan per meter.

\section{References}

[1] Q. C. Gao, L. Y. Weng,: Study on blasting damage and supporting methods of tunnel surrounding rock (National Symposium on Mine Construction, China 2005).

[2] X. X. Dong, P. Shao: Blasting Engineering (China Architecture \& Building Press, China 2005)

[3] W. L. Wang: Borehole Blasting (China Coal Industry Publishing House, China 1984) 